Vol. 12, No. 2

ISSN: 2085 - 4609 (Print), e- ISSN 2656-0208

Journal homepage: bit.ly/UltimaComm

\title{
Perilaku Konsumen terhadap Kualitas e-Service pada e-Commerce
}

\section{Nufian S. Febriani, Wayan Weda Asmara Dewi, \& Fitria Avicenna}

To cite this article:

Febriani, N.S., Dewi, W.W.A., \& Avicenna, F. (2020). Perilaku Konsumen terhadap Kualitas e-Service pada eCommerce, 12(2), 240-261. DOI 10.31937/ultimacomm.v12i2.1533

Ultimacomm publishes research articles and conceptual paper in the field of communication, mainly digital journalism and strategic communication. It is published twice a year by the Faculty of Communication of Universitas Multimedia Nusantara

Submit your article to this journal $₫$

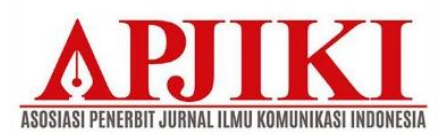

Full Terms \& Conditions of access and use can be found at http://ejournals.umn.ac.id/index.php/FIKOM/about 


\title{
Perilaku Konsumen terhadap Kualitas e-Service pada e-Commerce
}

\author{
Nufian S. Febriani, Wayan Weda Asmara Dewi, Fitria Avicenna \\ Universitas Brawijaya \\ Email:nufian.febriani@ub.ac.id, wayanwedaasmaradewi@ub.ac.id \\ fitria.avicenna@ub.ac.id
}

Received Apr. 4, 2020; First revision on Oct. 5, 2020; Second Revision on Nov. 11, 2020; Accepted Dec. 28, 2020

\begin{abstract}
Abstrak
Pola perilaku belanja masyarakat saat ini telah bergeser dari offline menjadi online. Tren belanja online memicu munculnya bisnis baru bernama e-commerce. Di Indonesia, ecommerce mulai banyak bermunculan, yang menyebabkan persaingan antar e-commerce semakin ketat. Oleh karena itu diperlukan suatu strategi komunikasi pemasaran untuk memenangkan persaingan antar e-commerce, salah satunya adalah dengan menerapkan kualitas e-service. Dengan menerapkan kualitas e-service yang baik maka kepuasan pelanggan akan muncul. Melalui penelitian ini, peneliti menemukan signifikansi pengaruh kualitas e-service terhadap kepuasan konsumen e-commerce. Secara akademis, penelitian ini dapat mengembangkan kajian ilmu komunikasi, khususnya topik perubahan perilaku kognitif konsumen e-commerce di Indonesia dan menjadi dasar pengambilan keputusan bagi pengambil strategi komunikasi pemasaran dalam mempromosikan, menjaga, dan meningkatkan kualitas dan kepuasan konsumen, khususnya untuk konsumen digital. Secara praktis, penelitian ini dapat memberikan informasi tentang pentingnya pengaruh kualitas penggunaan e-service terhadap kepuasan konsumen e-commerce di Indonesia. Manfaat praktis lain yang diperoleh melalui penelitian ini adalah tim strategi komunikasi pemasaran dapat mempertimbangkan/mengimplementasikan elemen apa saja dalam ecommerce yang dapat menarik perhatian konsumen digital. Penelitian ini menggunakan skala diferensial semantik yang mengukur perasaan subjektif seseorang dengan menggunakan berbagai kata sifat karena orang biasanya mengkomunikasikan evaluasi melalui kata sifat. Hasil penelitian menunjukkan bahwa kualitas e-service yang dilakukan oleh e-commerce di Indonesia dapat mempengaruhi kepuasan pelanggan.
\end{abstract}

Kata Kunci: Perilaku konsumen, e-service, e-commerce, kepuasan pelanggan, strategi komunikasi pemasaran 


\begin{abstract}
Nowadays, the pattern of shopping behavior has shifted from offline to online. The trend of online shopping triggers the emergence of a new business called e-commerce. In Indonesia, this has caused competition among e-commerce to become tighter. Therefore, it is necessary to have a marketing communication strategy to win the competition between e-commerce one of which is to implement e-service quality. By implementing good e-service quality, customer satisfaction will emerge. Through this study, researchers found the significance of the effect of e-service quality on e-commerce consumer satisfaction. Academically, this research can develop communication science studies, specifically the topic of changes in the cognitive behavior of e-commerce consumers in Indonesia and become the basis for decision making for marketing communication strategy in promoting, maintaining, and enhancing consumer quality and satisfaction, especially for digital consumers. Practically, this research can provide information about the significance of the influence of the use of e-service quality on e-commerce consumer satisfaction in Indonesia. Another practical benefit that can be obtained through this research is that the marketing communication strategy team can consider/implement any elements in e-commerce that can attract the attention of digital consumers. This research uses a semantic differential scale that measures a person's subjective feelings using various adjectives because people usually communicate evaluation through adjectives. The results show that e-service quality conducted by e-commerce in Indonesia can affect customer satisfaction.
\end{abstract}

Keywords: Consumer behavior, e-service, e-commerce, customer satisfaction, marketing communication strategies

\title{
PENDAHULUAN
}

Terjadi banyak perubahan dalam aspek kehidupan masyarakat. Salah satu bentuk perubahan yang saat ini tampak nyata adalah bidang teknologi dan gaya hidup manusia. Masyarakat modern telah menggunakan teknologi sebagai bagian dari gaya hidup yang praktis. Saat ini pola perilaku berbelanja masyarakat telah bergeser dari offline menuju online.

Tren belanja online memicu kemunculan bisnis baru yang disebut dengan e-commerce. Ini adalah kegiatan melakukan transaksi bisnis secara online melalui media internet dan beragam perangkat yang terintregasi dengan internet. Pada umumnya e-commerce merupakan transaksi yang terjadi dalam internet dan web (Laudon et.al., 2014). Saat ini, telah banyak perusahaan e-commerce yang beroperasi di Indonesia dan ini berbanding lurus dengan banyaknya konsumen yang melakukan pembelian atau sekadar mencari informasi produk melalui situs e-commerce. 
Gambar 1. Aktivitas e-commerce di Indonesia

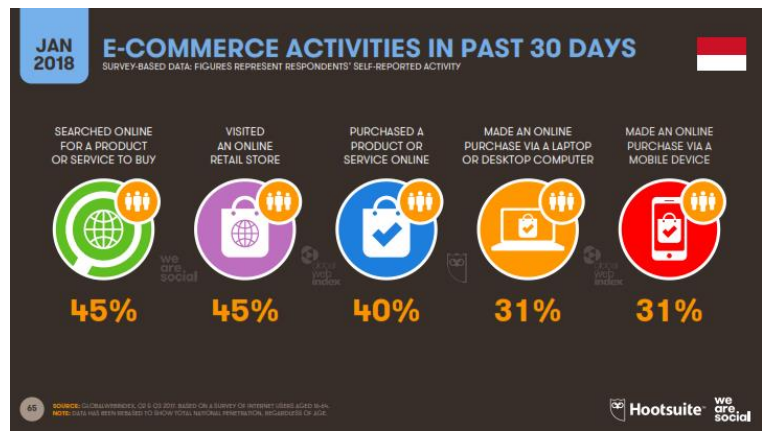

Sumber: www.wearesocial.com (2019)

Gambar di atas merupakan hasil survei yang dilakukan oleh We Are Social. Hasil menunjukkan bahwa dari pelaku kegiatan e-commerce, sebesar $45 \%$ melakukan pencarian produk atau layanan yang ingin dibeli. Sebesar $45 \%$ mengunjungi toko online. Sebesar $40 \%$ melakukan pembelian produk atau pelayanan secara online melalui $e$ commerce. Survei tersebut dilakukan dalam jangka waktu 30 hari terakhir pada Januari 2018. Selain itu, riset Google dan Tamasek, dalam laporannya e-Conomy SEA 2018, menyatakan bahwa Gross Merchandise Value atau GMV Industri e-commerce Indonesia merupakan yang tertinggi di Asia Tenggara mengalahkan Malaysia, Filipina, Singapura, Thailand, dan Vietnam (Tempo, 2018). Menurut survei yang dilakukan oleh iPrice Group terdapat lima e-commerce terpopuler, yakni Lazada, Tokopedia, Bukalapak, Blibli, dan Shopee. Ini dilihat berdasarkan jumlah kunjungan ke website tiap bulannya, ranking aplikasi, jumlah followers di media sosial, dan jumlah karyawan (Fajriana, 2018).

Besarnya peluang yang terdapat pada bidang e-commerce membuat para pelaku $e$ commerce di Indonesia saling berlomba untuk memberikan pelayanan yang terbaik agar dapat menarik perhatian serta membentuk positioning yang kuat bagi konsumen. Pelayanan jasa berbeda dengan produk. Jika pada produk, konsumen bisa langsung memberikan penilaian terhadap apa yang diberikan oleh produsen, namun pada pelayanan jasa penilaian baru dapat dilakukan setelah konsumen merasakan manfaat dari layanan tersebut. Perusahaan tentunya berharap dapat memberikan kualitas pelayanan yang terbaik kepada konsumennya, namun tidak semua konsumen memiliki penilaian yang sama terhadap kualitas pelayanan yang diberikan perusahaan. Ketidakpuasan konsumen pasti akan selalu ada dan perlu diminimalisir oleh perusahaan dengan memberikan kualitas pelayanan yang maksimal kepada konsumennya baik secara offline maupun online.

Rita et al., 2019 menyebutkan bahwa layanan jasa yang berbasis online disebut dengan eservice quality (e-servqual). E- -Servqual didefinisikan sebagai sejauh mana sebuah situs website memfasilitasi belanja, pembelian, dan pengiriman produk atau jasa yang efisien dan efektif. Setelah menyediakan e-service quality, kemudian e-commerce melakukan layanan yang akan menghasilkan tingkat kepuasan konsumen atas pelayanan yang telah diberikan. Kepuasan konsumen adalah tingkat perasaan seseorang setelah 
membandingkan kinerja atau hasil yang dirasakan dibandingkan dengan harapan. Kepuasan merupakan hasil dari perceived performance (perhitungan) dan expectations (harapan). Apabila kinerja produk atau jasa lebih rendah dari harapan, konsumen akan merasa tidak puas. Jika kinerja sesuai harapan maka konsumen akan merasa puas. Pada saat kinerja sampai melebihi harapan, maka konsumen akan merasa delighted (sangat puas) (Ahrholdt et al., 2019). Oleh karena itu penting bagi e-commerce untuk meningkatkan mutu pelayanan e-service quality agar konsumen merasa puas.

Beberapa studi pendahuluan yang dilakukan terhadap kepuasan konsumen pada $e$ commerce di Indonesia menunjukkan bahwa kepuasan berada pada level yang tidak cukup tinggi. Salah satu penyebab rendahnya kepuasan tersebut adalah kualitas pelayanan yang dianggap tidak baik atau tidak maksimal. Hasil penelitian terdahulu yang dilakukan oleh Widyanita (2018) menunjukkan bahwa Shopee sebagai salah satu platform e-commerce di Indonesia memiliki kinerja kualitas pelayanan yang rendah sehingga menurunkan tingkat kepuasan konsumennya.

Penelitian lain yang dilakukan oleh Lestari (2018) menunjukkan bahwa kepuasan konsumen dipengaruhi langsung oleh kualitas pelayanan dengan nilai kontribusi untuk pengaruh website sebesar $10.5 \%$, kualitas produk $14.5 \%$, dan kualitas layanan $57.2 \%$. Hasil serupa juga dapat ditemukan pada penelitian terdahulu yang menggunakan variabel $\mathrm{X}$ kualiatas pelayanan dan variabel $\mathrm{Y}$ kepuasan konsumen.

Berdasarkan beberapa studi terdahulu yang ditemukan oleh peneliti, ditemukan bahwa penelitian tentang e-commerce di Indonesia menggunakan satu objek penelitian $e$ commerce saja dan mengukur pengaruh kualitas pelayanan terhadap kepuasan konsumen pada penggunaan e-commerce tertentu. Dalam penelitian yang dilakukan saat ini, peneliti menggunakan e-commerce di Indonesia sebagai objek penelitian untuk mengukur kualitas pelayanan terhadap kepuasan konsumen. E-commerce yang digunakan adalah sepuluh $e$ commerce yang popular di Indonesia yang dikumpulkan dari SimilarWeb dalam rentang Januari-Desember 2019.

\section{TINJAUAN LITERATUR}

\section{E-Commerce}

Perkembangan internet dan teknologi turut mengubah model bisnis yang berkembang saat ini, seperti halnya model bisnis perdagangan elektronik yang lebih dikenal dengan $e$ commerce. E-commerce adalah lingkungan digital yang memungkinkan transaksi komersial terjadi di antara banyak organisasi dan individu. Banyak perusahaan yang saat ini memperkenalkan produk yang mereka jual melalui internet.

Akter et al., 2016 menyebutkan bahwa penggunaan teknologi berbasis internet yang sedang berkembang menyediakan e-commerce perusahaan dengan manfaat yang transformatif, misalnya, real time customer service, harga dinamis, penawaran yang dipersonalisasi, atau interaksi yang ditingkatkan. Sementara transaksi komersial di Indonesia melibatkan pertukaran nilai, misalnya uang, melintasi batas-batas organisasi atau individu sebagai imbalan atas barang dan jasa. 
Dalam penelitian Yi Cui (2019) disebutkan bahwa keberhasilan e-commerce ditentukan oleh perilaku penjual dan keputusan mereka tentang platform mana yang akan digunakan antara e-commerce berbasis aplikasi atau media sosial. Maka bentuk e-commerce yang dipilih penjual untuk mempengaruhi perilaku konsumen dapat dibedakan menjadi tiga. Pertama adalah B2C (Bussiness to Customer), yakni perdagangan elektronik yang melibatkan produk ritel dan layanan kepada pembeli individual. Kedua adalah B2B (Bussiness to Bussiness), yaitu perdagangan elektronik yang melibatkan penjual barang dan jasa antara pebisnis. Terakhir adalah C2C (Customer to Customer), yakni perdagangan elektronik yang melibatkan konsumen yang menjual langsung kepada konsumen (Kotler, 2012).

\section{E-Service Quality}

Kualitas pelayanan merupakan suatu hal penting yang harus diperhatikan oleh setiap perusahaan. Bagi sebuah perusahaan, kualitas pelayanan yang baik dapat membedakannya dengan perusahaan kompetitornya serta dapat membentuk positioning bagi perusahaan. Konsep perilaku keterlibatan pelanggan didefinisikan sebagai manifestasi perilaku pelanggan terhadap suatu merek atau perusahaan, di luar pembelian, yang dihasilkan dari sebuah motivasi. Keterlibatan ini mempengaruhi e-service quality (E-Servqual) yang didefinisikan sebagai sejauh mana sebuah situs web memfasilitasi belanja, pembelian, dan pengiriman produk atau jasa yang efisien dan efektif (van Doorn, 2010).

Sedangkan menurut Carlson (2010), kualitas layanan elektronik didefinisikan sebagai evaluasi dan penilaian konsumen secara keseluruhan terhadap kualitas penyampaian layanan elektronik di pasar internet. Kualitas layanan elektronik digambarkan sebagai sebuah evaluasi dan penilaian pelanggan secara keseluruhan mengenai keunggulan dan kualitas pengiriman elektronik pada pasar dunia maya.

Zeithaml (2013) mengidentifikasi tujuh dimensi yang membentuk skala "core online services" dan skala "recovery online service". Empat dimensi inti yang digunakan pelanggan untuk menilai website di mana mereka tidak mengalami pertanyaan atau masalah adalah

1. Efficiency, yaitu kemudahan dan kecepatan dalam mengakses, menggunakan, dan meninggalkan situs.

2. Fullfillment, sejauh mana akurasi janji situs tentang ketersediaan pesanan dan kecepatan pengiriman produk.

3. Reliability, kebenaran fungsi teknis dari situs, khususnya apakah situs berfungsi sebagaimana mestinya.

4. Privacy, sejauh mana situs tersebut memberi jaminan keamanan dan perlindungan informasi pengguna. 
Tiga dimensi yang digunakan pelanggan untuk menilai layanan pemulihan saat mereka memiliki masalah atau pertanyaan adalah:

5. Responsiveness, kemampuan penanganan masalah yang efektif dan pengembalian garansi online.

6. Compensation, sejauh mana situs memberikan kompensasi kepada pelanggan yang mengalami permasalahan.

7. Contact, tersedianya bantuan melalui telepon atau online.

\section{E-Satisfaction (Kepuasan Konsumen Digital)}

Layanan pelanggan dapat mempengaruhi kepuasan konsumen. Menurut Kotler (2012) kepuasan konsumen adalah perasaan senang atau kecewa seseorang yang berasal dari perbandingan antara kesannya terhadap kinerja (atau hasil) suatu produk dan harapanharapannya. Menurut Ting et al. (2016), e-satisfaction digambarkan sebagai gratifikasi dari pelanggan yang berasal dari pengalaman pembelian nyata sebelumnya dengan perusahaan perdagangan elektronik tertentu. Menurut Ranjbarian et al. (2012), terdapat lima dimensi utama yang mempengaruhi e-satisfaction:

1. Convenience, dalam hal ini ialah kepuasan dalam waktu berbelanja, kenyamanan, dan kemudahan dalam menemukan kebutuhan.

2. Merchandising, dalam hal ini ialah kepuasan dalam jumlah promosi yang ditawarkan.

3. Site design, dalam hal ini ialah kepuasan dalam kemudahan menggunakan website, desain website, presentasi, dan informasi yang terbarui.

4. Security, dalam hal ini ialah kepuasan dalam perlindungan keamanan dan privasi pengguna

5. Serviceability, dalam hal ini ialah kepuasan dalam pelayanan dan kebijakan yang diberlakukan.

\section{Rujukan Data Penelitian Terdahulu}

Penelitian pertama yang dijadikan rujukan berjudul Pengaruh E-Service Quality terhadap E-Customer Satisfaction dan E-customer Loyalty pada Lazada.co.id (Djatmiko, 2011). Penelitian ini bertujuan untuk mengetahui penilaian pelanggan terhadap variabel $e$ service quality, e-customer satisfaction, dan e-customer loyalty. Selain itu, penelitian ini juga bertujuan untuk mengevaluasi pengaruh variabel e-service quality, e-customer satisfaction, dan e-customer loyalty. Jenis penelitian yang digunakan pada penelitian ini adalah deskriptif kausal. Pengumpulan data dilakukan dengan cara penyebaran kuesioner kepada pelanggan dari situs belanja online Lazada.co.id yang telah melakukan transaksi lebih atau sama dengan dua kali. Jumlah sampel sebanyak 385 orang yang ditentukan dengan metode nonprobability purposive sampling. Teknik analisis yang digunakan adalah Structural Equation Model (Pemodelan Persamaan Struktural), biasa disingkat dengan SEM. 
Hasil penelitian mengungkapkan bahwa e-service quality berpengaruh positif dan signifikan terhadap e-customer satisfaction, e-customer satisfaction berpengaruh positif dan signifikan terhadap e-customer loyalty, e-service quality berpengaruh positif dan signifikan terhadap e-customer loyalty dan e-service quality memiliki pengaruh tidak langsung terhadap e-customer loyalty melalui e-customer satisfaction.

Penelitian lain terkait ini berjudul Pengaruh E-Service Quality terhadap E-Satisfaction pada Pengguna di Situs Tokopedia (Tobagus, 2018). Penelitian ini bertujuan untuk mengetahui pengaruh e-service quality terhadap e-satisfaction. Selain itu juga, penelitian ini dilakukan untuk mengukur penilaian pembeli terhadap e-service quality, dan $e$ satisfaction di situs Tokopedia. Penelitian ini menggunakan metode kuantitatif, dan pengumpulan data dilakukan dengan cara penyebaran angket secara online kepada pembeli di situs Tokopedia yang telah melakukan transaksi minimal dua kali, dengan jumlah sampel sebanyak 137 orang. Teknik penarikan sampel yaitu nonprobability sampling dengan teknik analisis menggunakan regresi linier sederhana.

Hasil menunjukkan bahwa nilai koefisien korelasi sebesar 0,903 dan nilai koefisien determinasi ( $R$ Square) sebesar 0,815 atau 81,5\%. Berdasarkan hal tersebut, dapat disimpulkan bahwa variabel e-service quality $(\mathrm{X})$ memberikan pengaruh terhadap variabel e-satisfaction ( $\mathrm{Y}$ ) sebesar $81,5 \%$, sedangkan sisanya, yaitu sebesar $18,5 \%$, dipengaruhi oleh faktor lain yang tidak diteliti dalam penelitian ini. Dapat diartikan bahwa antara variabel e-service quality $(\mathrm{X})$ dengan variabel $e$-satisfaction $(\mathrm{Y})$ memiliki hubungan yang positif dan signifikan.

Penelitian Jimanto (2014) berjudul Pengaruh Service Quality terhadap Loyalitas Pelanggan dengan Customer Satisfaction sebagai Variabel Intervening pada Ritel Bioskop The Premiere Surabaya adalah penelitian ketiga yang dijadikan rujukan untuk studi ini. Penelitian ini bertujuan untuk mengetahui pengaruh dari service quality (reliability, responsiveness, assurance, empathy, and tangible) terhadap customer satisfaction pada pelanggan The Premiere Surabaya (The Premiere Grand City, The Premiere Lenmarc, and The Premiere Ciputra World) dengan mempertimbangkan faktor customer loyalty. Teknik pengambilan data adalah dengan menyebarkan kuesioner terhadap 120 pelanggan The Premiere. Teknik analisis yang digunakan adalah analisis kuantitatif dengan metode Path Analysis dan Partial Least Square.

Hasil penelitian ini menunjukkan terdapat hubungan yang signifikan antara service quality dengan customer satisfaction pada The Premiere, hubungan signifikan juga antara service quality terhadap customer loyalty, dan tidak ada hubungan yang signifikan antara customer satisfaction terhadap customer loyalty pada The Premiere.

\section{Kerangka Pemikiran}

Penelitian ini akan menjelaskan pengaruh e-service quality terhadap kepuasan konsumen e-commerce di Indonesia. Berdasarkan tinjauan teoritis yang telah dipaparkan, maka peneliti membuat kerangka berpikir bahwa variabel independen yang terdiri dari e-service quality $(\mathrm{X})$ dan variabel dependen terdiri dari kepuasan konsumen $(\mathrm{Y})$. 
Gambar 2. Model kerangka pemikiran

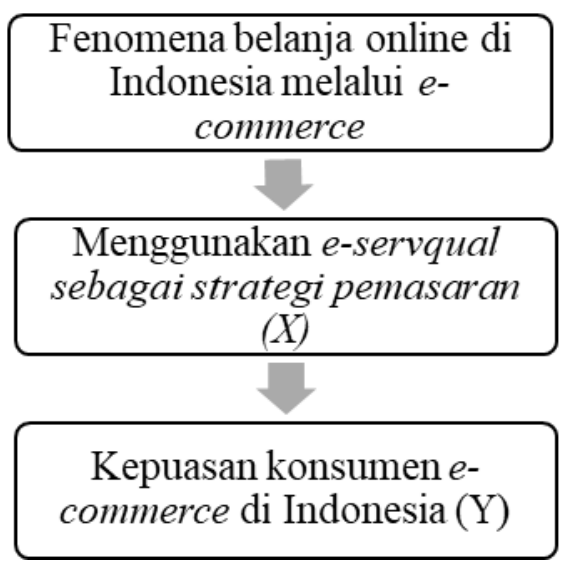

\section{Pertanyaan Penelitian}

Bagaimana e-service quality sebagai strategi pemasaran mempengaruhi kepuasan konsumen e-commerce di Indonesia.

\section{Konsep}

Penelitian ini menggunakan indikator dari Zeithaml et al. (2013) untuk membantu mengukur variabel e-service quality $(\mathrm{X})$, dan untuk mengukur variabel kepuasan konsumen pada e-commerce (Y) menggunakan indikator dari Ranjbarian et al. (2012). Berikut ini adalah detail untuk variabel dan indikator yang digunakan dalam penelitian ini:

Tabel 1. Konsep Variabel

\begin{tabular}{|c|c|}
\hline Variabel & Indikator \\
\hline \multirow{4}{*}{ E-service quality } & Efficiency \\
\cline { 2 - 2 } & Fullfillment \\
\cline { 2 - 2 } & Reliability \\
\cline { 2 - 2 } & Privacy \\
\cline { 2 - 2 } & Responsiveness \\
\cline { 2 - 2 } Kepuasan & Compensation \\
Konsumen & Contact \\
\hline e-commerce & Convenience \\
\cline { 2 - 2 } & Merchandising \\
\cline { 2 - 2 } & Site design \\
\cline { 2 - 2 } & Security \\
\cline { 2 - 2 } & Serviceability \\
\hline
\end{tabular}




\section{METODE}

Jenis penelitian ini adalah kuantitatif dengan tujuan untuk menjelaskan suatu masalah atau kejadian yang dapat digeneralisasikan. Penelitian kuantitatif merupakan metode tradisional, karena metode ini sudah cukup lama digunakan sehingga sudah mentradisi sebagai metode untuk penelitian (Sugiyono, 2015).

Penelitian ini menggunakan jenis riset eksplanatif. Menurut Neuman (2013) tujuan utama dari jenis riset ini adalah menjelaskan alasan terjadinya peristiwa dan membentuk, memperdalam, mengembangkan, atau menguji teori. Hubungan antarvariabel yang akan dibuktikan dalam penelitian ini adalah pengaruh e-service quality terhadap kepuasan konsumen dengan responden konsumen e-commerce di Indonesia. Penelitian ini mencoba menjelaskan sebab akibat dari dua variabel yang terdiri dari variabel independen e-service quality terhadap variabel dependen kepuasan konsumen $e$ commerce di Indonesia. Penelitian eksplanatif bertujuan untuk menjelaskan kedudukankedudukan dari variabel-variabel yang diteliti serta hubungan antara satu variabel dengan variabel lainnya (Sugiyono, 2010).

Metode penelitian yang digunakan dalam penelitian ini adalah survei menggunakan instrumen berupa kuesioner. Dalam penelitian ini, peneliti menetapkan yang menjadi populasi adalah konsumen e-commerce di Indonesia.

Sampel yang diambil dalam penelitian ini sejumlah 116 responden yang didapatkan dari hasil penghitungan menggunakan rumus Slovin. Teknik pengambilan sampel (sampling) menggunakan probability sampling, yaitu teknik pengambilan sampel yang memberi peluang yang sama bagi setiap anggota populasi.

Untuk dapat mengukur indikator dengan baik, peneliti menetapkan penggunaan skala Likert sebagai parameter pengukuran. Neuman (2013, p.255) mengatakan bahwa skala Likert sering digunakan dalam penelitian survei dengan orang yang menyatakan sikap atau tanggapan yang sehubungan dengan tingkat ordinal (misal, setuju, tidak setuju) yang diperingkatkan secara kontinum.

Instrumen dalam penelitian ini diujikan kepada sejumlah responden terlebih dahulu. Uji instrumen yang dilakukan adalah uji validitas dan uji reliabilitas dengan jenis validitas dan reliabilitas konstruk. Uji instrumen ini dilakukan pada responden yang bukan bagian dari sampel penelitian. Setelah kuesioner dinyatakan valid dan reliable menggunakan rumus product moment yang diolah dalam SPSS (Statistical Product and Service Solution) V27, kuesioner kemudian diberikan kepada sample sebenarnya dalam penelitian ini.

Teknik analisis data yang digunakan antara lain uji asumsi klasik menggunakan empat alat uji (uji normalitas, uji auto korelasi, uji linieritas dan uji heterokedastisitas) dengan tujuan untuk memastikan bahwa di dalam sebuah model regresi linear Ordinary Least Square (OLS) tidak terdapat masalah dalam sebaran datanya. Peneliti juga menggunakan uji linier sederhana dan One Way ANOVA untuk menguji hipotesis. Semua dilakukan menggunakan SPSS V27 untuk input data dan olah data. 


\section{HASIL}

Sample diperoleh melalui tautan google form yang disebarkan secara acak pada kelompok komunitas UMKM di Indonesia yang menggunakan e-commerce untuk diberikan kepada konsumennya, sehingga didapatkan responden sejumlah 116 orang. Profil responden dalam penelitian ini adalah 63\% perempuan, $78 \%$ berusia $18-23$ tahun, 73\% belum menikah, 70\% berlokasi di Indonesia bagian barat, 57\% pelajar/mahasiswa dan $56 \%$ berpenghasilan antara Rp 1.500.000-Rp 2.500.000. Setelah peneliti mengadakan penelaahan yang mendalam terhadap berbagai sumber untuk menentukan anggapan dasar, maka langkah berikutnya adalah merumuskan hipotesis (Arikunto, 2010).

Berdasarkan kerangka berpikir di atas, penulis merumuskan hipotesis sebagai berikut:

$\mathrm{HO}=$ Terdapat pengaruh signifikan antara penggunaan e-service quality terhadap kepuasan konsumen commerce di Indonesia.

$\mathrm{H} 1$ = Tidak terdapat pengaruh signifikan antara penggunaan e-service quality terhadap kepuasan konsumen e-commerce di Indonesia.

Uji hipotesis dilakukan dengan cara membandingkan antara nilai thitung masing-masing variabel bebas dengan nilai $t_{\text {tabel }}$ dengan derajat kesalahan $5 \%(\alpha=0.05)$. Berdasarkan hasil uji hipotesis koefisien regresi variabel dalam penelitian ini, yaitu e-service quality sebagai variabel $(\mathrm{X})$ terhadap Kepuasan Konsumen sebagai variabel $(\mathrm{Y})$, diperoleh nilai $t_{\text {hitung }}$ sebesar 18.531 dan didapatkan nilai signifikansi sebesar 0,000 . Maka, $t_{\text {hitung }}>t_{\text {tabel }}$ $(18.531>1.984)$ dan nilai signifikansi lebih kecil daripada $\alpha=0,05$. Hipotesis yang diajukan, hasil serta perhitungan yang diperoleh menunjukkan bahwa hipotesis awal diterima dan hipotesis akhir ditolak. Maka, penelitian ini menunjukkan bahwa terdapat pengaruh signifikan antara penggunaan e-service quality terhadap kepuasan konsumen e-commerce di Indonesia. Berikut ini adalah sajian hasil dari penelitian ini:

Pengaruh E-service quality menurut Zeithaml (2013) dalam penelitian ini diperoleh dari hasil perhitungan tujuh indikator, yaitu e-service quality. Ini terdiri dari Efficiency, Fullfillment, Reliability, Privacy, Responsiveness, Compensation, dan Contact, yang digunakan pelanggan untuk menilai situs web. Sedangkan menurut Ranjbarian (2012), terdapat lima indikator yang mempengaruhi kepuasan konsumen, yaitu Convenience, Merchandising, Site design, Security, dan Serviceability. Dalam hal ini, indikator-indikator tersebut dapat digunakan untuk mengukur e-service quality dan kepuasan konsumen pada pembeli online.

Berikut merupakan indikator dari variabel E-service quality $(\mathrm{X})$ :

1. Efficiency

Indikator pertama untuk e-service quality adalah Efficiency. Aspek ini digunakan untuk mengukur kemudahan dan kecepatan dalam mengakses, menggunakan, dan meninggalkan situs. Pada indikator ini terdapat dua item pernyataan yang masingmasing bertujuan untuk mengukur tingkat kemudahan akses pada situs. 
Gambar 3. Diagram Efficiency

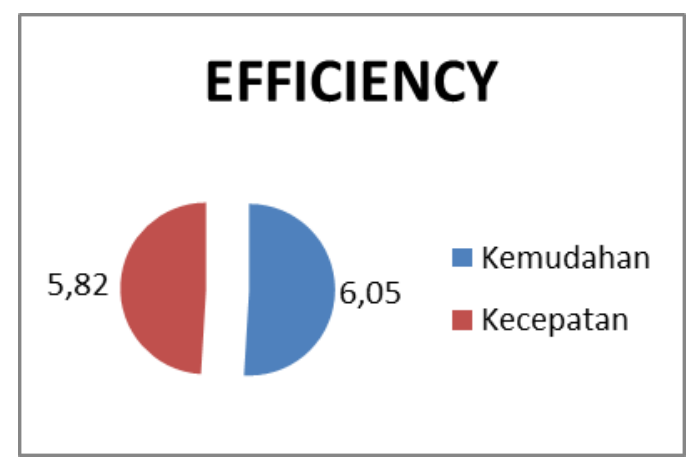

Sebanyak 39 responden mengatakan sepakat atau setuju, pada sakala 6 dengan ratarata 6,05 untuk item pertanyaan pertama, yaitu kemudahan e-commerce untuk menemukan apa yang dibutuhkan (misalnya produk, metode pembayaran, bantuan keluhan, dan lain-lain). Hal ini berarti menurut responden mudah dalam menemukan kebutuhan pada situs e-commerce.

Item pernyataan kedua adalah situs di e-commerce memuat halaman dengan cepat. Pada item ini dapat dilihat bahwa 38 responden mengatakan sepakat setuju pada skala 6 atau dengan rata-rata 5,60. Hal ini berarti menurut responden pengoperasioan pada situs e-commerce cepat. Dengan demikian, responden pada indikator Efficiency cenderung setuju dengan rata-rata sebesar 5,82 .

\section{Fullfillment}

Indikator kedua untuk e-service quality adalah Fullfillment. Aspek ini digunakan untuk mengukur sejauh mana akurasi janji situs tentang ketersediaan pesanan dan kecepatan pengiriman produk. Pada indikator ini terdapat dua item pernyataan yang masing-masing bertujuan untuk mengukur tingkat kejujuran pada situs.

Gambar 4. Diagram Fullfillment

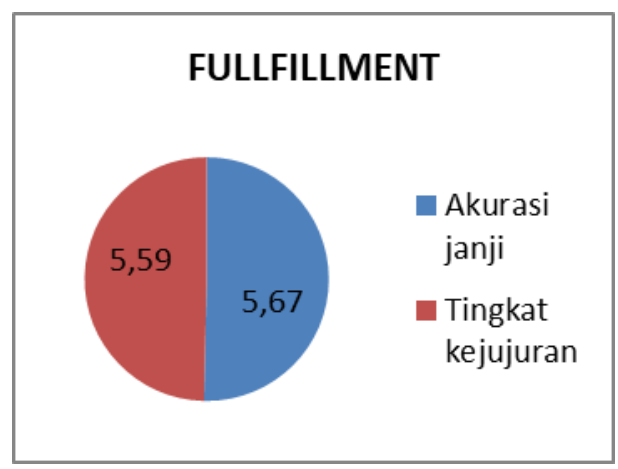

Item pernyataan ketiga yaitu Situs e-commerce jujur atas setiap penawaran yang diberikan (misal, promo yang ditawarkan sesuai pada saat pembayaran). Dapat dilihat bahwa 30 responden mengatakan sepakat setuju pada skala 6 dan 5 atau dengan ratarata 5,59. Hal ini berarti menurut responden situs e-commerce jujur terhadap konsumen. 
Item pernyataan keempat yaitu Situs e-commerce selalu menepati janji (misal, menjaga aktivitas belanja saya selalu aman, nyaman, dan sebagainya). Pada item pertanyaan ini dapat dilihat bahwa 36 responden mengatakan sepakat setuju pada skala 6 atau dengan rata-rata 5,67. Hal ini berarti menurut responden pada situs $e$ commerce dikatakan selalu menepati janji terhadap konsumen. Dengan demikian, responden pada indikator Fullfillment cenderung setuju dengan rata-rata sebesar 5,63.

\section{Reliability}

Indikator ketiga untuk e-service quality adalah reliability. Aspek ini digunakan untuk mengukur kebenaran fungsi teknis dari situs khususnya apakah situs berfungsi sebagaimana mestinya. Pada indikator ini terdapat dua item pernyataan yang masingmasing bertujuan untuk mengukur tingkat akurasi pada situs.

Gambar 5. Diagram Reliability

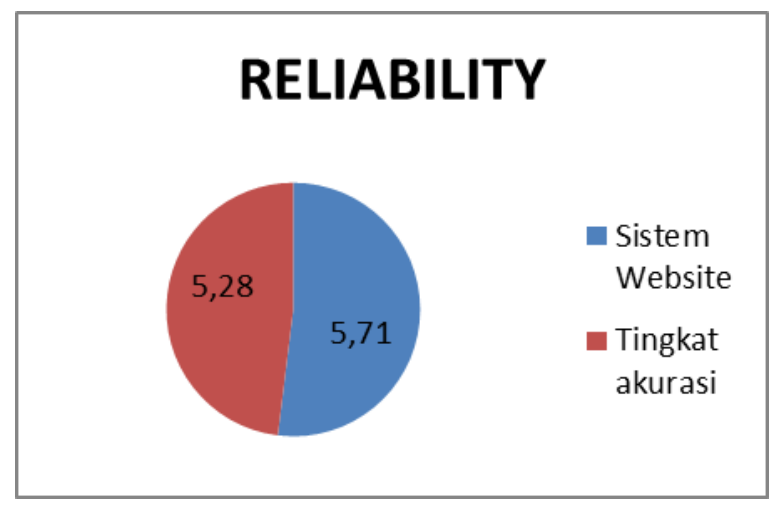

Item pernyataan kelima yaitu Sistem website e-commerce menjalankan permintaan pembeli secara akurat. Dapat dilihat bahwa 47 responden mengatakan sepakat setuju pada skala 6 atau dengan rata-rata 5,71. Hal ini berarti menurut responden situs $e$ commerce akurat.

Sebanyak 29 responden sepakat setuju pada skala lima atau dengan rata-rata 4,86 untuk item pernyataan keenam, yaitu sistem website e-commerce jarang terjadi kesalahan. Hal ini berarti menurut responden pada situs e-commerce jarang terjadi kesalahan. Dengan demikian, responden pada indikator Reliability cenderung setuju dengan rata-rata sebesar 5,28.

\section{Privacy}

Indikator keempat untuk e-service quality adalah Privacy, yakni aspek yang digunakan untuk mengukur sejauh mana situs memberi jaminan keamanan dan perlindungan informasi pengguna. Pada indikator ini terdapat tiga item pernyataan yang masingmasing bertujuan untuk mengukur tingkat keamanan pengguna pada situs. 
Gambar 6. Diagram Privacy

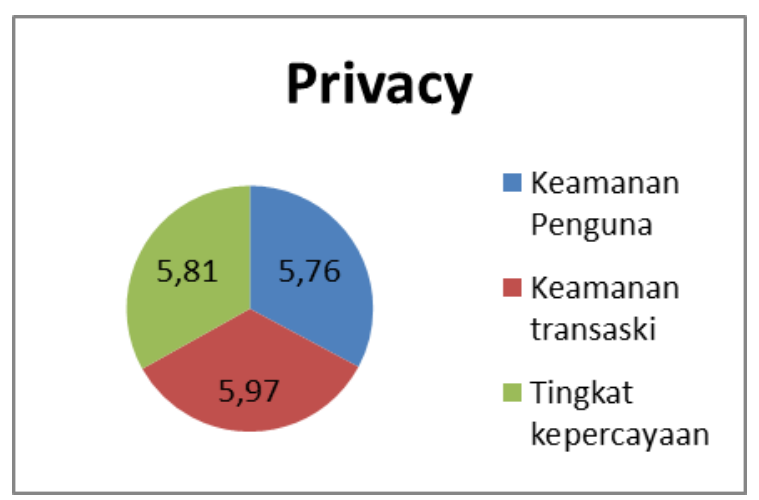

Item pernyataan ketujuh adalah situs e-commerce melindungi informasi tentang aktivitas belanja saya. Pada item ini dapat dilihat bahwa 34 responden mengatakan sepakat setuju pada skala 6 atau dengan rata-rata 5,76. Hal ini berarti menurut responden situs e-commerce melindungi informasi pribadi konsumen.

Sebanyak 36 persen responden mengatakan sepakat setuju pada skala 7 atau dengan rata-rata 5,97 untuk item pernyataan kedelapan, yaitu situs e-commerce melindungi informasi transaksi saya (kartu kredit/debit, dan lain sebagainya). Hal ini berarti menurut responden situs e-commerce melindungi informasi pribadi konsumen.

Item pernyataan kesembilan yaitu saya merasa bisa mempercayai situs e-commerce untuk berbelanja. Di sini dapat dilihat bahwa 31 responden mengatakan sepakat setuju pada skala 6 atau dengan rata-rata 5,71. Hal ini berarti menurut responden situs e-commerce dapat dipercaya. Dengan demikian, responden pada indikator Privacy cenderung setuju dengan rata-rata sebesar 5,81 .

\section{Responsiveness}

Indikator kelima untuk e-service quality adalah Responsiveness. Aspek ini digunakan untuk mengukur kemampuan penanganan masalah yang efektif dan pengembalian garansi online. Pada indikator ini terdapat empat item pernyataan yang masing-masing bertujuan untuk mengukur tingkat penanganan masalah pada situs. 


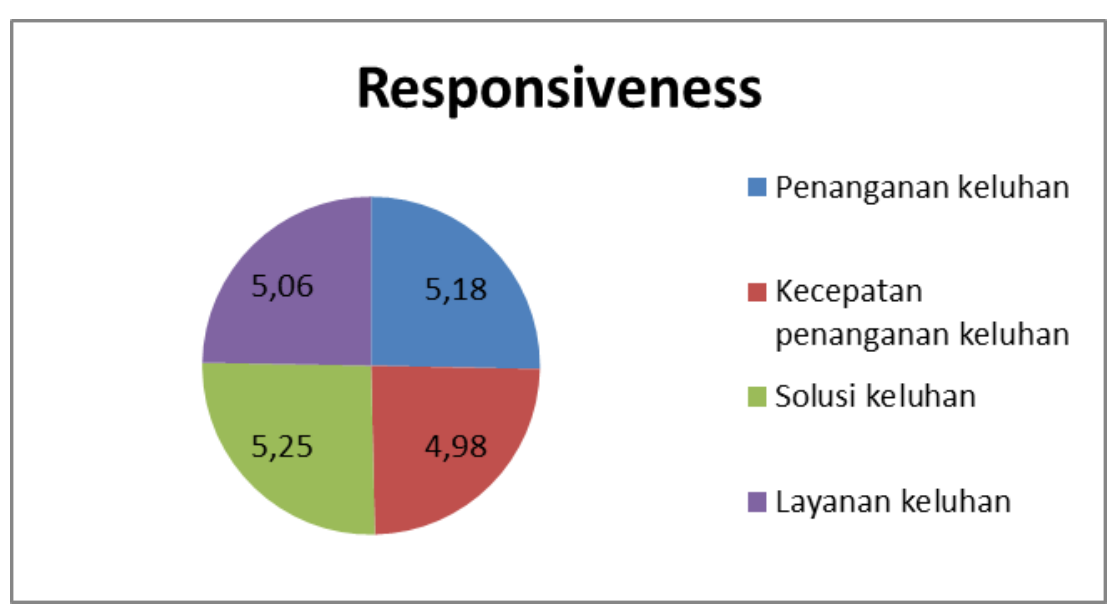

Item pernyataan kesepuluh yaitu situs e-commerce menangani masalah/keluhan pembelian saya dengan sederhana. Pada item ini dapat dilihat bahwa 31 responden mengatakan sepakat setuju pada skala 6 atau dengan rata-rata 5,18. Hal ini berarti menurut responden situs e-commerce menangani keluhan dengan sederhana.

Sebanyak 31 responden mengatakan sepakat setuju pada skala 5 atau dengan ratarata 4,98 untuk item pernyataan kesebelas, yaitu situs e-commerce menangani masalah/keluhan pembelian saya dengan segera. Hal ini berarti menurut responden situs e-commerce menangani keluhan dengan cepat.

Item pernyataan kedua belas yaitu Situs e-commerce memberitahu saya apa yang harus dilakukan jika transaksi belanja saya mengalami masalah (tidak terproses, dan sebagainya). Dapat dilihat bahwa 33 responden mengatakan sepakat setuju pada skala 6 atau dengan rata-rata 5,25. Hal ini berarti menurut responden situs e-commerce dapat memberikan arahan dengan baik ketika terdapat keluhan.

Ada 31 responden sepakat atau setuju pada skala 6 atau dengan rata-rata 4,85 untuk item pernyataan ketiga belas, yaitu situs e-commerce menanggapi masalah/keluhan belanja saya dalam waktu 24 jam. Hal ini berarti menurut responden situs e-commerce cepat dalam menanggapi keluhan. Dengan demikian, responden pada indikator Responsiveness cenderung setuju dengan rata-rata sebesar 5,06.

\section{Compensation}

Indikator keenam untuk e-service quality adalah Compensation. Aspek ini digunakan untuk mengukur sejauh mana situs memberikan kompensasi kepada pelanggan yang mengalami permasalahan. Pada indikator ini terdapat satu item pernyataan yang bertujuan untuk mengukur tingkat penanganan masalah dalam hal kompensasi pada situs. 
Item pernyataan keempat belas yaitu situs e-commerce menawarkan refund/return/tukar barang jika tidak sesuai, ingin ganti produk, dan sebagainya. Pada item ini dapat dilihat bahwa 36 responden mengatakan sepakat setuju pada skala 6 atau dengan rata-rata 5,34. Hal ini berarti menurut responden situs e-commerce memberikan kesempatan refund kepada konsumen. Dengan demikian, responden pada indikator Compensation cenderung setuju dengan rata-rata sebesar 5,34.

\section{Contact}

Indikator keempat untuk E-service quality adalah Contact, aspek ini digunakan untuk mengukur tersedianya bantuan melalui telepon atau online. Pada indikator ini terdapat dua item pernyataan yang masing-masing bertujuan untuk mengukur tingkat kontak bantuan pada situs.

Gambar 8. Diagram Contact

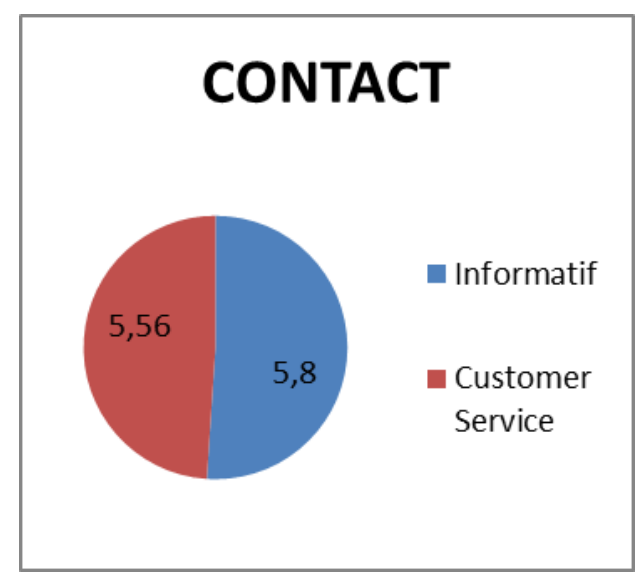

Item pernyataan kelima belas yaitu situs web e-commerce menyediakan kontak (telepon, email, dan lain-lain) untuk mengatasi masalah/keluhan belanja saya. Di sini dapat dilihat bahwa 40 responden mengatakan sepakat setuju pada skala 6 atau dengan rata-rata 5,8. Hal ini berarti menurut responden situs e-commerce telah memberikan informasi yang jelas terkait kontak customer service.

Item pernyataan keenam belas yaitu situs e-commerce memiliki customer service yang tersedia secara online. Pada item ini dapat dilihat bahwa 39 responden mengatakan sepakat setuju pada skala 6 atau dengan rata-rata 5,66. Hal ini berarti menurut responden situs e-commerce memberikan pelayanan customer service secara online. Dengan demikian, responden pada indikator Contact cenderung setuju dengan ratarata sebesar 5,73 .

Berdasarkan data Kementerian Kominfo (Menkominfo) RI tahun 2017, sebesar 53,70\% setiap orang di Indonesia mencari informasi mengenai barang atau jasa di internet. Persentase tersebut merupakan angka terbesar kedua dalam kategori aktivitas menggunakan internet oleh individu. Hal ini diperkuat oleh pendapat Ketua Umum 
Asosiasi Pengusaha Ritel Indonesia, Roy Mandey (2017), bahwa masyarakat Indonesia tengah mengalami perubahan perilaku, khususnya dalam pola belanja.

Variabel Kepuasan Konsumen (Y) memiliki beberapa indikator yang dijelaskan sebagai berikut:

Gambar 9. Diagram Kepuasaan Konsumen

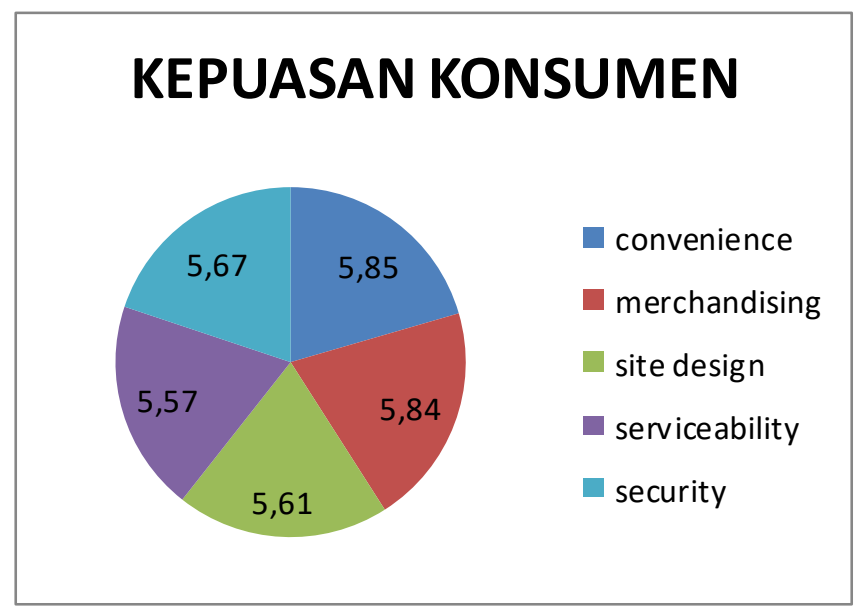

\section{Convenience}

Indikator pertama untuk Kepuasan Konsumen adalah Convenience. Aspek ini digunakan untuk mengukur kepuasan dalam waktu berbelanja, kenyamanan, dan kemudahan dalam menemukan kebutuhan. Pada indikator ini terdapat tiga item pernyataan yang masing-masing bertujuan untuk mengukur tingkat kepuasan melalui pengalaman berbelanja pada situs.

Item pernyataan ketujuh belas yaitu saya puas dengan menggunakan waktu saya untuk berbelanja di situs e-commerce. Di sini dapat dilihat bahwa 51 responden mengatakan sepakat setuju pada skala 6 atau dengan rata-rata 5,83. Hal ini berarti responden merasa puas berbelanja di situs e-commerce berdasarkan efisiensi waktu.

Item pernyataan kedelapan belas yaitu Saya puas dengan pengalaman selama berbelanja di situs e-commerce. Di sini dapat dilihat bahwa 42 responden mengatakan sepakat setuju pada skala 6 atau dengan rata-rata 5,76. Hal ini berarti responden merasa puas berbelanja di situs e-commerce berdasarkan pengalamannya.

Sebanyak 37 responden mengatakan sepakat setuju pada skala 6 atau dengan ratarata 5,98 untuk item pernyataan kesembilan belas, yaitu saya benar-benar menikmati aktivitas berbelanja di situs e-commerce. Hal ini berarti responden merasa puas dan 
menikmati berbelanja di situs e-commerce. Dengan demikian, responden pada indikator Convenience cenderung setuju dengan rata-rata sebesar 5,85.

\section{Merchandising}

Indikator kedua untuk Kepuasan Konsumen adalah Merchandising, yang digunakan untuk mengukur kepuasan dalam jumlah promosi yang ditawarkan. Pada indikator ini terdapat tiga item pernyataan yang masing-masing bertujuan untuk mengukur tingkat kepuasan berbelanja melalui promosi yang ditawarkan pada situs.

Item pernyataan kedua puluh yaitu saya puas dengan kemudahan dalam menemukan apa saja yang saya butuhkan di situs e-commerce, misalnya pencarian produk, penawaran promosi, bantuan informasi, dan lain-lain. Pada item ini dapat dilihat bahwa 37 responden mengatakan sepakat setuju pada skala 6 atau dengan rata-rata 5,91 . Hal ini berarti responden merasa puas berbelanja di situs e-commerce berdasarkan kemudahan menemukan kebutuhannya.

Sebanyak 34 responden mengatakan sepakakt setuju pada skala 6 atau dengan ratarata 5,68 untuk item pernyataan kedua puluh satu yaitu saya puas dengan jumlah penawaran (promosi) di situs e-commerce. Hal ini berarti responden merasa puas berbelanja di situs e-commerce berdasarkan promosi yang ditawarkan.

Item pernyataan kedua puluh dua yaitu saya puas dengan keberagaman (promosi), misalnya discount, gratis ongkos kirim, dan lain-laindi situs e-commerce. Dapat dilihat bahwa 39 responden mengatakan sepakat setuju pada skala 7 atau dengan rata-rata 5,94 . Hal ini berarti responden merasa puas berbelanja di situs e-commerce berdasarkan keberagaman promosi yang ditawarkan. Dengan demikian, responden pada indikator Merchandising cenderung setuju dengan rata-rata sebesar 5,84.

\section{Site design}

Indikator ketiga untuk Kepuasan Konsumen adalah Site design. Aspek ini digunakan untuk mengukur kepuasan dalam kemudahan menggunakan website, desain website, presentasi, dan informasi yang terbarui. Pada indikator ini terdapat empat item pernyataan yang masing-masing bertujuan untuk mengukur tingkat kepuasan berbelanja melalui website $e$-commerce.

Sebanyak 39 responden mengatakan sepakat setuju pada skala 6 atau dengan ratarata 5,75 untuk item pernyataan kedua puluh tiga, yaitu saya puas dengan navigasi/panduan arah dalam menemukan menu pencarian, login, dan lain-lain di situs e-commerce. Hal ini berarti responden merasa puas berbelanja di situs e-commerce berdasarkan kemudahan menggunakan website.

Item pernyataan kedua puluh empat yaitu saya puas dengan tampilan website di situs e-commerce. Pada item ini dapat dilihat bahwa 39 responden mengatakan sepakat setuju pada skala 6 atau dengan rata-rata 5,63. Hal ini berarti responden merasa puas berbelanja di situs e-commerce berdasarkan tampilan website. 
Item pernyataan kedua puluh lima yaitu saya puas dengan semua presentasi yang ada di website e-commerce. Di sini dapat dilihat bahwa 37 responden mengatakan sepakat setuju pada skala 6 atau dengan rata-rata 5,40. Hal ini berarti responden merasa puas berbelanja di situs e-commerce berdasarkan presentasi website.

Item pernyataan kedua puluh enam yaitu saya puas dengan update informasi yang ada di situs e-commerce. Pada item ini dapat dilihat bahwa 39 responden mengatakan sepakat setuju pada skala 6 atau dengan rata-rata 5,68. Hal ini berarti responden merasa puas berbelanja di situs e-commerce berdasarkan kebaruan informasi yang ditampilkan pada website. Dengan demikian, responden pada indikator Site design cenderung setuju dengan rata-rata sebesar 5,61.

\section{Security}

Indikator keempat untuk Kepuasan Konsumen adalah Security. Aspek ini digunakan untuk mengukur kepuasan dalam perlindungan keamanan dan privasi pengguna. Pada indikator ini terdapat dua item pernyataan yang masing-masing bertujuan untuk mengukur tingkat kepuasan berbelanja melalui keamanan pengguna.

Item pernyataan kedua puluh tujuh yaitu saya puas bahwa e-commerce melindungi privasi saya dengan baik, misalnya aktivitas belanja. Dapat dilihat bahwa 45 responden mengatakan sepakat setuju pada skala 6 atau dengan rata-rata 5,68. Hal ini berarti responden merasa puas berbelanja di situs e-commerce berdasarkan perlindungan privasi konsumen.

Sebanyak 37 responden mengatakan sepakat setuju pada skala 6 atau dengan ratarata 5,67 untuk item pernyataan kedua puluh delapan yaitu saya puas dengan keamanan transaksi di situs e-commerce, misalnya keamanan dari pembobolan kartu kredit/debit. Hal ini berarti responden merasa puas berbelanja di situs e-commerce berdasarkan keamanan bertransaksi. Dengan demikian, responden pada indikator Security cenderung setuju dengan rata-rata sebesar 5,67.

\section{Serviceability}

Indikator keempat untuk Kepuasan Konsumen adalah Serviceability. Aspek ini digunakan untuk mengukur kepuasan dalam pelayanan dan kebijakan yang diberlakukan. Pada indikator ini terdapat lima item pernyataan yang masing-masing bertujuan untuk mengukur tingkat kepuasan berbelanja melalui kebijakan yang berlaku di e-commerce.

Item pernyataan kedua puluh sembilan adalah saya puas dengan pelayanan complaint di situs e-commerce. Di sini dapat dilihat bahwa 31 responden mengatakan sepakat setuju pada skala 6 atau dengan rata-rata 5,27. Hal ini berarti responden merasa puas berbelanja di situs e-commerce berdasarkan pelayanan complaint.

Sejumlah 40 responden mengatakan sepakat setuju pada skala 6 atau dengan ratarata 5,76 untuk item pernyataan ketiga puluh, yaitu saya puas dengan kelengkapan 
informasi (history penjual, status pengiriman, dan lain-lain) di situs e-commerce. Hal ini berarti responden merasa puas berbelanja di situs e-commerce berdasarkan kelengkapan informasi.

Item pernyataan ketiga puluh satu yaitu saya puas dengan kebijakan pengembalian di situs e-commerce. Dapat dilihat bahwa 37 responden mengatakan sepakat setuju pada skala 6 atau dengan rata-rata 5,5. Hal ini berarti responden merasa puas berbelanja di situs e-commerce berdasarkan kebijakan refund.

Item pernyataan ketiga puluh dua yaitu saya puas dengan layanan purna jual di situs $e$ commerce, misalnya pembeli bisa mengajukan refund/return/tukar barang jika barang tidak sesuai. Pada item ini dapat dilihat bahwa 41 responden mengatakan sepakat setuju pada skala 6 atau dengan rata-rata 5,48. Hal ini berarti responden merasa puas berbelanja di situs e-commerce berdasarkan kebijakan pasca pembelian.

Sebanyak 48 responden mengatakan sepakat setuju pada skala 6 atau dengan ratarata 5,86 untuk item pernyataan ketiga puluh tiga, yaitu secara keseluruhan saya puas dengan pelayanan selama berbelanja di situs e-commerce. Hal ini berarti responden merasa puas berbelanja di situs e-commerce berdasarkan keseluruhan pelayanan. Dengan demikian, responden pada indikator Serviceability cenderung setuju dengan rata-rata sebesar 5,57 .

\section{PEMBAHASAN}

Dari hasil jawaban responden terhadap e-service quality pada situs e-commerce, diperoleh total keseluruhan mean 5,50. Dengan melihat nilai tersebut maka, e-service quality di situs e-commerce sudah baik. Namun, pada e-service quality terkait indikator Reliability pada pernyataan "Situs e-commerce menanggapi masalah/keluhan belanja saya dalam waktu 24 jam" menjadi pernyataan yang memiliki nilai terendah di variabel $e$ service quality. Hal ini, memang masih menjadi kendala pada beberapa situs e-commerce, yang terkadang masih kurang sigap dalam menanggapi keluhan konsumen. Dari hasil jawaban responden terhadap kepuasan konsumen pada situs e-commerce, maka diperoleh total keseluruhan mean adalah 5,70. Dengan melihat nilai tersebut maka konsumen pengguna di situs e-commerce di Indonesia menurut responden sudah puas.

Dari hasil kedua variabel dapat dikatakan bahwa situs e-commerce di Indonesia dalam hal memberi kenyamanan, kemudahan, dan kecepatan berbelanja, unggul pada indikator efficiency dalam variabel e-service quality dengan rata-rata 5.82 dan pada indikator convenience dalam variabel kepuasan konsumen dengan rata-rata 5.85 . Hal ini berarti $e$ commerce di Indonesia mengutamakan kenyamanan, kemudahan dan kecepatan bertransaksi bagi penggunanya. Sedangkan dari hasil kedua variabel, dapat dikatakan bahwa situs e-commerce di Indonesia dalam hal penanganan masalah dan kebijakan masih kurang atau rendah dibanding indikator yang lainnya. Hal tersebut terlihat pada indikator responsiveness dalam variabel e-service quality dengan rata-rata 5.06 dan pada indikator serviceability dalam variabel kepuasan konsumen dengan rata-rata 5.57. Hal ini 
berarti e-commerce di Indonesia masih rendah dalam penanganan masalah dan kebijakan bagi konsumen.

Hasil dari uji regresi linier sederhana, menunjukkan bahwa variabel e-service quality (X) memberikan pengaruh yang positif dan signifikan terhadap variabel kepuasan konsumen (Y) sebesar 88,2\%. Terlihat dari nilai koefisien korelasi (R) sebesar 0.882 atau 88,2\%. Penelitian ini didukung dengan penelitian terdahulu oleh Anita Tobagus (2018) yang menunjukkan bahwa e-service quality terbukti sebagai salah satu faktor yang berpengaruh terhadap kepuasan konsumen secara online atau e-satisfaction. Sementara sisanya, yaitu sebesar 18,5\%, dipengaruhi oleh faktor lain yang bukan bagian dari $e$ service quality.

Hubungan antara e-service quality dengan kepuasan konsumen dikatakan juga memiliki hubungan yang searah. Hal ini dapat dilihat pada nilai koefisien arah regresi adalah positif, yaitu sebesar 0,981, artinya jika ada penambahan satu nilai atau angka pada variabel e-service quality $(\mathrm{X})$ maka akan ada kenaikan pada variable kepuasan konsumen (Y) sebesar 0,981. Ini berarti bila e-service quality semakin baik maka kepuasan konsumen dari pengguna online juga akan meningkat. Sebaliknya, jika e-service quality buruk akan menurunkan tingkat kepuasan konsumen pengguna online. Penelitian ini juga sejalan dengan Kotler (2012), di mana kepuasan merupakan fungsi dari perceived performance (kinerja yang dirasakan) dan expectations (harapan). Maka, menjadi penting bagi $e-$ commerce untuk meningkatkan mutu pelayanan e-service quality agar konsumen merasa puas.

Hasil pengujian hipotesis dengan menggunakan uji t juga menunjukkan bahwa e-service quality berpengaruh signifikan terhadap e-satisfaction pada pengguna di situs Tokopedia dengan t hitung sebesar 18.531 dan nilai t tabel sebesar 1.984. Sesuai dengan kriteria pengujian maka jika nilai $\mathrm{t}$ hitung $>\mathrm{t}$ tabel maka, variabel independen berpengaruh terhadap variabel dependen. Nilai signifikansi sebesar 0,000 lebih kecil dari 0,05 artinya variabel independen berpengaruh secara signifikan terhadap variabel dependen. Hal ini berarti bahwa dengan adanya e-service quality yang baik atau buruk akan memberikan pengaruh yang signifikan terhadap e-satisfaction pengguna pada situs e-commerce di Indonesia. Penelitian ini didukung dengan penelitian terdahulu yang diteliti oleh Akbar dan Djatmiko (2016) yang menunjukkan bahwa e-service quality secara signifikan mempengaruhi kepuasan konsumen dari pembeli online.

\section{SIMPULAN DAN KETERBATASAN}

Variabel E-service quality (X) memiliki pengaruh secara langsung terhadap Kepuasan Konsumen $(Y)$ e-commerce di Indonesia karena memiliki nilai probalitas $(0,000)<0,05$ yang berarti ada pengaruh yang signifikan. Didapatkan hasil bahwa situs e-commerce di Indonesia unggul dalam hal memberi kenyamanan, kemudahan dan kecepatan berbelanja namun masih rendah dalam hal penanganan masalah dan kebijakan bagi konsumen.

Penelitian ini menggunakan skala diferensial semantik yang mengukur perasaan subjektif seseorang dengan menggunakan berbagai kata sifat karena orang biasanya mengomunikasikan evaluasi melalui kata sifat, sehingga diperoleh data yang lebih 
komprehensif tentang kepuasan tehadap e-service quality yang dirasakan saat berbelanja. Hasil menunjukkan bahwa e-service quality yang dilakukan oleh e-commerce di Indonesia, dapat mempengaruhi kepuasan konsumennya.

\section{REFERENSI}

Ahrholdt, et al. (2019). Enhancing loyalty: When improving consumer satisfaction and delight matters. Journal of Business Research, 94, 18-27. https:doi.org/10.1016/j.jbusres.2018.08.040

Akbar, A \& Djatmiko. (2016). Pengaruh e-Service Quality terhadap E-Customer Satisfaction dan E-Customer Loyalty pada lazada. co. id. E-proceedings of the Management, 3(1), 142-150. Retrieved from https://libraryeproceeding.telkomuniversity.ac.id/index.php/management/article/ viewFile/2978/2824.

Akter, S \& Samuel F. W. (2016). Big data analytics in E-commerce: a systematic review and agenda for future research. Electron Markets, 26(2), 173-194. https://doi.org/10.1007/s12525-016-0219-0

Anggraini, K. (2018, November 28). Transaksi E-Commerce Di Indonesia Tertinggi di Asia Tenggara. Retrieved April 02, 2020 from https://bisnis.tempo.co/read/1150204/transaksi-e-commerce-indonesia-tertinggidi-asia-tenggara bisnis.tempo.com.

Carlson, J. \& O'Cass, A. (2010). Exploring the relationships between e-service quality, satisfaction, attitudes and behaviours in content-driven e-service web sites. Journal of Services Marketing, 24(2), 112127. https://doi.org/10.1108/08876041011031091.

Cui, Y., Mou, J., Cohen, J. et al. (2019). Understanding information system success model and valence framework in sellers' acceptance of cross-border e-commerce: a sequential multi-method approach. Electronic Commerce Research, 19(4), 885-914. https://doi.org/10.1007/s10660-019-09331-0

Fajriana, M. (2018, Mei 31). Cara Seru Generasi Milenial Peduli dengan Lingkungan. Retrieved August 7, 2019 from https://www.liputan6.com/fashionbeauty/read/3543477/cara-seru-generasi-milenial-peduli-dengan-lingkungan

Jimanto, R. B. (2014). Pengaruh Service Quality Terhadap Loyalitas Pelanggan Dengan Customer Satisfaction Sebagai Variabel Intervening pada Ritel Bioskop The Premiere Surabaya. Jurnal Strategi Pemasaran, 2(1),1-7.

Kominfo. (2017). Data dan Statistik. Retrieved December 9, 2017 from https://statistik.kominfo.go.id/site/data?idtree $=424 \&$ iddoc $=1521$

Kotler, P., \& Keller, K. L.. (2012). Marketing Management $\left(14^{\text {th }}\right.$ ed.) New Jersey: Prentice Hall.

Laudon, K. C. et al. (2014). Management Information Systems Managing The Digital Firm (13 ${ }^{\text {th }}$ ed.). Pearson: Global Edition

Lestari, F. A. P. (2018). Pengaruh Web E-Commerce, Kualitas Produk dan Kualitas Layanan Terhadap Kepuasan Konsumen. Sosio e-Kons, 10(1), 87-95. http://dx.doi.org/10.30998/sosioekons.v10i1.2411

Neuman, W. L. (2013). Metode Penelitian Sosial: Pendekatan Kualitatif dan Kuantitatif. Jakarta: Indeks. 
Ranjbarian, B. \& Rezaei, Z. (2012). Factors Influencing on Customers' E-Satisfaction: A case Study from Iran. Interdisciplinary Journal of Contemporary Research In Business, 3(9), 1496-1511.

Rita, P., Oliveira, T., \& Farisa, A. (2019). The impact of e-service quality and customer satisfaction on customer behavior in online shopping. Heliyon, 5(10), e02690. https://doi.org/10.1016/j.heliyon.2019.e02690

Sugiyono. (2015). Metode Penelitian Kombinasi (Mixed Methods). Bandung: Alfabeta.

Ting, Ong \& Md Ariff, Mohd Shoki \& Zakuan, Norhayati \& Sulaiman, Zuraidah \& Saman, Muhamad. (2016). E-Service Quality, E-Satisfaction and E-Loyalty of Online Shoppers in Business to Consumer Market; Evidence form Malaysia. IOP Conference Series: Materials Science and Engineering. 131. 012012. 10.1088/1757899X/131/1/012012.Tobagus,A. (2018). Pengaruh E-Service Quality Terhadap ESatisfaction Pada Pengguna di Situs Tokopedia, Agora, 6(1), 1-10.

van Doorn, J., Lemon, K. N., Mittal, V., Nass, S., Pick, D., Pirner, P., \& Verhoef, P. C. (2010). Customer Engagement Behavior: Theoretical Foundations and Research Directions. Journal of Service Research, 13(3), 253-266. https://doi.org/10.1177/1094670510375599.

We Are Social. (2019). Indonesian Digital Report 2019. Retrieved April 2, 2020 from https://andi.link/hootsuite-we-are-social-indonesian-digital-report-2019/.

Widyanita, F.A. (2018). Analisis Pengaruh Kualiatas Pelayanan E-Commerce Terhadap Kepuasan Konsumen Shopee Indonesia Pada Mahasiswa Fakultas Ekonomi UII Pengguna Shopee [Undergraduate Thesis, Universitas Islam Indonesia]. Repository of Universitas Islam Indonesia. Retrieved from https://dspace.uii.ac.id/handle/123456789/7821.

Zeithaml, V.A., Bitner, M.J.,\& Gremler, D.D. (2013). Services Marketing: Integrating Customer Focus Across the Firm (6 $6^{\text {th }}$ ed.). Boston: Mc.Graw-Hill. 